\title{
ENZYMATIC ANTIOXIDANT RESPONSES TO BIOSTIMULANTS IN MAIZE AND SOYBEAN SUBJECTED TO DROUGHT
}

\author{
Ana Carolina Feitosa de Vasconcelos ${ }^{1}$; Xunzhong Zhang²; Erik H. Ervin²; Jorge de Castro \\ $\mathrm{Kiehl}^{3 *}$ \\ ${ }_{2}^{1}$ R. da Represa, 89 apto 23, Itacorubi - 88034-350 - Florianópolis, SC - Brasil. \\ ${ }^{2}$ Virginia Polytechnic Institute and State University - Dept. of Crop and Soil Environmental Sciences, 24061-0404 - \\ Blacksburg, VA - USA. \\ ${ }^{3}$ USP/ESALQ - Depto. de Ciência do Solo, C.P. 09 - 13418-900 - Piracicaba, SP - Brasil. \\ *Corresponding author <jdckiehl@esalq.usp.br>
}

\begin{abstract}
Water stress is one of the most important environmental factors inducing physiological changes in plants, such as decrease in the water potential of the cells, the stomatal closure; and the development of oxidative processes mediated by reactive oxygen species (ROS). Antioxidant enzymes superoxide dismutase (SOD), catalase (CAT), and ascorbate peroxidase (APX) are efficient scavengers of ROS. The aim of this research was to examine how the application of biostimulant based on humic substances and aminoacids may affect activity levels of SOD, CAT, and APX of maize and soybean plants under well-watered or drought stress conditions. Pots (4.5 L) were filled with a Typic Hapludult soil where the biostimulants doses were applied. It was taken leaf samples in order to analyze SOD, CAT, and APX activities in plants. SOD and APX activity levels were increased by application of biostimulant 1 in maize subjected to stress. Catalase activity was not enhanced in plants by using the biostimulants. The composition of the biostimulants was not able to enhance stress tolerance in maize and soybean plants subjected to water stress.
\end{abstract}

Key words: superoxide dismutase, catalase, ascorbate peroxidase, water status

\section{RESPOSTAS DE ENZIMAS ANTIOXIDANTES A BIOESTIMULANTES EM PLANTAS DE MILHO E DE SOJA SOB ESTRESSE HÍDRICO}

RESUMO: O estresse hídrico é um dos mais importantes fatores ambientais que induz mudanças fisiológicas, como diminuição do potencial de água na célula, o fechamento dos estômatos e o desenvolvimento de processos oxidativos mediante a formação das espécies reativas de oxigênio (ROS). As enzimas antioxidantes superóxido dismutase (SOD), catalase (CAT) e ascorbato peroxidase (APX) são eficientes eliminadores das ROS. O objetivo deste estudo foi examinar como a aplicação de bioestimulantes com substâncias húmicas e aminoácidos em sua composição afeta os níveis de SOD, CAT e APX nos tecidos das folhas de plantas de milho e de soja cultivadas com ou sem estresse hídrico. Amostras de um Argissolo foram colocadas em vasos (4,5 L) onde foram adicionadas as doses dos bioestimulantes. Foram retiradas amostras de folhas para análise da atividade da SOD, CAT e APX nas plantas. A SOD e APX aumentaram nas plantas de milho com a aplicação do bioestimulante 1. A atividade da CAT não aumentou nas plantas com a aplicação dos bioestimulantes. As composições dos bioestimulantes não possibilitaram aumento na resistência ao estresse hídrico em plantas de milho e de soja submetidas ao estresse hídrico

Palavras-chave: superoxide dismutase, catalase, ascorbate peroxidase, status hídrico

\section{INTRODUCTION}

Plants are subjected to several environmental stresses that adversely affect growth, metabolism, and yield. Drought is a major abiotic factor that limits agricultural crop production and plants respond to water stress depending on their growth stage as well as the severity and duration of the stress (Reddy et al., 2004). In the cellular level, membranes and proteins can be damaged by a reduction in hydration and increase of reactive oxygen species (ROS) (Artlip \& Wisniewski, 2002; Castrillo et al., 2001). For a long time ROS have been considered mainly as dangerous molecules, but it has been realized that ROS play im- 
portant roles in defense system of plants (Schützendüubel \& Polle, 2002; Rahman et al., 2004).

Once formed, ROS must be detoxified as efficiently as possible to minimize eventual damage. The detoxification mechanisms constitute the second line of defense against the detrimental effects of ROS (Gratão et al., 2005). Plant cells are protected by a complex antioxidant system comprised of non-enzymic as well as enzymic antioxidants, such as superoxide dismutase (SOD), catalase (CAT), and ascorbate peroxidase (APX) (Noctor \& Foyer, 1998). A close relationship between antioxidant activity and stress tolerance has been identified in several crops (Malan et al., 1990; Perl et al., 1993; Zhang et al., 2003; Zhang \& Ervin, 2004). Any potential tool available to crop managers for improving overall plant performance and quality during exposure to environmental stress would likely be a welcome addition to an already existing agronomic fertility program. In this way, biostimulants are available in a variety of formulations and ingredients, but they are generally classified into three major groups on the basis of their source and content: humic substances, hormone containing products, and amino acid containing products (Akande, 2006). Hormone containing products, such as seaweed extracts, contain identifiable amounts of active plant growth substances such as auxins, cytokinins, or their derivatives (Kauffman III et al., 2007).

Humic acids have been used in the composition of biostimulants to improve the antioxidant system in plants subjected to environmental stresses, since they present phytohormonal activities (O'Donnell, 1973; Canellas et al, 2008; Eyheraguibel et al., 2008). Under water stress, fertilization with humic acids increased leaf water retention and antioxidant metabolism (Delfine et al., 2005). Biostimulants have exhibited antioxidant activity in plants under stress (Zhang \& Schmidt, 2000) since there are evidences that plant physiological fitness is largely governed by hormonal balance and antioxidant defense systems (Zhang et al., 2005).

The objectives of this research were to investigate how the application of biostimulants affect the levels of SOD, CAT, APX in leaves of maize and soybean plants under well-watered or drought stress conditions.

\section{MATERIAL AND METHODS}

This research was conducted in a greenhouse in Blacksburg, $\left(37^{\circ} 12^{\prime} \mathrm{N}, 80^{\circ} 25^{\prime} \mathrm{W}\right)$, VA, USA, from October to December 2005. Three biostimulants were selected for this study and their characteristics are given in Table 1.
Table 1 - Characterization of the biostimulants employed in the greenhouse study.

\begin{tabular}{|c|c|c|c|}
\hline \multirow{2}{*}{ Parameter } & \multicolumn{3}{|c|}{ Biostimulant } \\
\hline & BIO1 & $\mathrm{BIO} 2$ & $\mathrm{BIO} 3$ \\
\hline $\mathrm{pH}$ & 4.7 & 1.50 & 13.0 \\
\hline Total N ( $\left.\mathrm{g} \mathrm{L}^{-1}\right)$ & 98.0 & 14.0 & 4.6 \\
\hline Total $\mathrm{P}_{2} \mathrm{O}_{5}\left(\mathrm{~g} \mathrm{~L}^{-1}\right)$ & 19.4 & 233.8 & 0.06 \\
\hline $\mathrm{K}_{2} \mathrm{O}\left(\mathrm{g} \mathrm{L}^{-1}\right)$ & 22.0 & 5.6 & 63.0 \\
\hline $\mathrm{Ca}\left(\mathrm{g} \mathrm{L}^{-1}\right)$ & 0.40 & 0.41 & 4.9 \\
\hline $\operatorname{Mg}\left(\mathrm{g} \mathrm{L}^{-1}\right)$ & 1.1 & 0.7 & 1.9 \\
\hline $\mathrm{S}\left(\mathrm{g} \mathrm{L}^{-1}\right)$ & 52.1 & 1.1 & 10.1 \\
\hline $\mathrm{Cu}\left(\mathrm{mg} \mathrm{dm}{ }^{-3}\right)$ & 47 & 3 & 2.0 \\
\hline $\mathrm{Fe}\left(\mathrm{mg} \mathrm{dm}{ }^{-3}\right)$ & 360 & 162 & 1890 \\
\hline $\operatorname{Mn}\left(\mathrm{mg} \mathrm{dm}^{-3}\right)$ & 235 & 7 & 18 \\
\hline $\mathrm{Zn}\left(\mathrm{mg} \mathrm{dm}^{-3}\right)$ & 98 & 6000 & 6 \\
\hline Organic Matter $\left(\mathrm{g} \mathrm{L}^{-1}\right)$ & 384.6 & 145.5 & 102.5 \\
\hline Total Carbon $\left(\mathrm{g} \mathrm{L}^{-1}\right)$ & 213.7 & 80.8 & 56.9 \\
\hline Humic Acid ( $\left.\mathrm{g} \mathrm{L}^{-1}\right)$ & 71.3 & - & 163.6 \\
\hline Fulvic Acid $\left(\mathrm{g} \mathrm{L}^{-1}\right)$ & 120.3 & 185.4 & 84.3 \\
\hline C/N Ratio & $2 / 1$ & $6 / 1$ & $13 / 1$ \\
\hline Density $\left(\mathrm{g} \mathrm{mL}^{-1}\right)$ & 1.25 & 1.24 & 1.16 \\
\hline
\end{tabular}

The biostimulants were tested using a modified version of the standard Avena Coleoptile Straight Segment Growth Bioassay for auxin activity outlined by Yopp et al. (1986), modified by Zhang et al. (2005). Briefly, seeds of oat were surface sterilized by immersion in 2\% sodium hypochlorite solution for $5 \mathrm{~min}$ and then rinsed in tap water for one hour. The seeds were soaked for two hours in distilled water and then placed embryo down on tissue paper supported by a plastic frame $1.5 \mathrm{~cm}$ for the bottom of a plastic tray containing distilled water to a $1 \mathrm{~cm}$ depth. Seeds were then incubated at $23^{\circ} \mathrm{C}, 30 \mathrm{~cm}$ below a red light source for $20 \mathrm{~h}$ and then an additional $80-90 \mathrm{~h}$ at $25^{\circ} \mathrm{C}$ once the coleoptiles reached $20 \mathrm{~mm}$ in length. Under green light, the coleoptiles were cut $3 \mathrm{~mm}$ below their tip into two $5 \mathrm{~mm}$ segments which were transferred to Petri dishes ( $5 \mathrm{~cm}$ diameter; 6 segments per dish). Each dish received $5.6 \mathrm{~mL}$ of potassium phosphate $(5 \mathrm{mM}, \mathrm{pH} 4.8)$, citric acid $(2.5 \mathrm{mM})$ buffer, and $560 \mu \mathrm{L}$ of biostimulant. It was prepared two replications for each biostimulant. After an additional $20 \mathrm{~h}$ of incubation, the length of the segments was measured to the nearest $0.1 \mathrm{~mm}$. A standard auxin curve was prepared for comparison. Auxin in an aqueous solution of $1 \mathrm{mg} \mathrm{L}^{-1}$ concentration was used to deliver in $10 \mu \mathrm{L}$ to $100 \mu \mathrm{L}$ amounts $(0,10,25$, $50,75,100 \mu \mathrm{L})$ to each dish. After 30 hours of incubation, the length of the segments was measured and the concentration of auxin in the biostimulants was calculated based on the standard curve. 
Table 2 - Chemical and physical properties of the soil employed in the experiment.

\begin{tabular}{|c|c|c|c|c|c|c|c|c|c|c|c|c|c|}
\hline $\begin{array}{l}\mathrm{pH} \\
\mathrm{H}_{2} \mathrm{O}\end{array}$ & $\mathrm{K}$ & $\mathrm{Ca}$ & $\mathrm{Mg}$ & Base Saturation & $\mathrm{P}$ & $\mathrm{Cu}$ & $\mathrm{Zn}$ & Mn & $\mathrm{Fe}$ & B & Sand & Silt & Clay \\
\hline & \multicolumn{3}{|c|}{ - $\mathrm{mmol}_{\mathrm{c}} \mathrm{dm}^{-3}$-...- } & $\%$ & \multicolumn{6}{|c|}{ mg dm ${ }^{-3}$} & \multicolumn{3}{|c|}{---- $\mathrm{g} \mathrm{kg}^{-1}-\cdots$} \\
\hline 5.7 & 1.9 & 15.6 & 5.5 & 81.5 & 34.1 & 0.1 & 2.1 & 9.0 & 8.7 & 0.3 & 630 & 290 & 80 \\
\hline
\end{tabular}

Pots were filled with 4.5 liters of a Typic Hapludult soil amended with fertilizer and lime, and analyzed for chemical and physical properties (Table 2) according to Virginia Cooperative Extension (VCE) guidelines (Mullins \& Heckendorn, 2005). Seeds of maize (Zea mays) hybrids Pioneer 30R75 and soybean (Glycine max) cultivar Camp were sown, and after seedling emergence, two plants of similar height were kept in each pot. The doses of the biostimulants (Table 3 ) were diluted in water and applied to the soil on two dates: 21 and 49 days after seeding. Treatments 1 and 2 were the recommended dose by the producers and a dose $100 \%$ higher than recommended, respectively.

\section{Drought Stress Treatment}

Two days after the first application of the biostimulants, plants were separated into water "stressed" and "unstressed" groups following ten weeks of growth and development under non-limiting soil moisture conditions. Plants in the "unstressed" group were maintained with a soil moisture approximately at field capacity $(-0.01 \mathrm{MPa} ; 200 \mathrm{~mL}$ per container by hand three times a week), while the "stressed" plants were maintained with moisture approximately near the permanent wilting point $(-1.5 \mathrm{MPa})$. The soil moisture content was controlled by daily weighing of pots and by monitoring with a ThetaProbe soil moisture sensor (ML1; Delta-T devices, Cambridge, UK) once a week. Moisture retention at $-0.01 \mathrm{MPa}$ and $-1.5 \mathrm{MPa}$ of the soil was estimated before treatment initiation with a standard pressure plate method (Klute, 1983; cited by Zhang \& Ervin, 2004). Three samples per matric potential were used.

\section{Antioxidant Enzymes Determinations}

Leaves of each pot were sampled for antioxidant enzyme activity in three dates: 21 days after seeding, immediately before the first application of the biostimulants (first sampling); 42 days after seeding (second sampling), and at the end of the experimental period (60 days after seeding - sampling 3). Samples were collected before applying the treatments. After collecting, the samples were immediately frozen with liquid $\mathrm{N}$ and stored at $-80^{\circ} \mathrm{C}$. Frozen leaf samples $(0.25 \mathrm{~g})$ were crushed with liquid $\mathrm{N}$ and extracted with a pestle in an ice-cold mortar with $4 \mathrm{~mL}$ of $0.05 \mathrm{M} \mathrm{Na}_{2} \mathrm{HPO}_{4} / \mathrm{NaH}_{2} \mathrm{PO}_{4}$ $\left(\mathrm{pH}\right.$ 7.0) buffer containing $0.2 \quad \mathrm{mM}^{4}$ ethylenediaminetetracetic acid (EDTA) and 1\% polyvinyl-pyrrolidone (PVP). The homogenates were centri-
Table 3 - Doses of the biostimulants utilized in the study.

\begin{tabular}{lccc}
\hline \multirow{2}{*}{ Biostimulants } & \multicolumn{3}{c}{ Doses $\left(\mathrm{L} \mathrm{ha}^{-1}\right)$} \\
\cline { 2 - 4 } & Control & Treatment 1 & Treatment 2 \\
\hline BIO1 & 0 & 150 & 300 \\
BIO2 & 0 & 0.5 & 1 \\
BIO3 & 0 & 25 & 50 \\
\hline
\end{tabular}

fuged at $4^{\circ} \mathrm{C}$ for $20 \mathrm{~min}$ at $15000 \mathrm{gn}$ (Zhang et al., 2005). The supernatants were collected and used for assays of enzymatic activities. The superoxide dismutase (SOD), catalase (CAT), and ascorbate peroxidase (APX) activities were determined according to the method of Giannopolitis \& Ries (1977), Chance \& Maehly, (1995), and Nakano \& Asada (1981), respectively.

The protein content in leaf tissues was determined using the bicinchoninic acid (BCA) procedure (Smith, 1985) in order to express the antioxidant enzyme assays based on protein content. One unit of SOD activity was defined as the amount of enzyme required to cause $50 \%$ inhibition of the rate of nitro blue tetrazolium reduction measured at $560 \mathrm{~nm}$ on a spectrophotometer. One unit of CAT and APX activities was defined as a change of 0.01 absorbance $\min ^{-1}$ and 0.1 absorbance $\mathrm{min}^{-1}$, respectively (Zhang et al., 2005).

\section{Experimental Design and Statistical Analysis}

A completely randomized design with a $3 \times 2$ factorial layout, with three replications, was employed: three doses of the biostimulants with and without drought stress, totaling 18 pots for each biostimulant and crop. The statistical analysis was performed with the SAS package version 8.2 for Windows (SAS Institute, 2002). Data were evaluated by analysis of variance and by the least significant difference (LSD) mean separation procedures at a $5 \%$ level of significance.

\section{RESULTS AND DISCUSSION}

The biostimulants contained a non-detectable concentration of auxin content, except the biostimulant BIO1, which was measured by the avena coleoptile segment straight growth bioassay and indicated to have $1.22 \mathrm{ng} \mathrm{g}^{-1}$ of auxin. Levels of auxin required for regulation of plant metabolic process and stimulation of enzyme activities are in the ng $\left(10^{-9}\right)$ to $\mu \mathrm{g}\left(10^{-6}\right)$ range (Zhang et al., 2005). 
The first measurement of SOD, APX and CAT activities (first sampling) are presented in Table 4. These values can be statistically compared to the values measured at 42 and 60 days after seeding (Tables 5, 6, and 7). Superoxide dismutase and APX activities were increased in maize plants under both soil moisture levels by application of BIO1 (Table 5). In soybean plants, only the APX activity at 42 days after seeding presented some increase by application of BIO
Table 4 - Superoxide dismutase (SOD), ascorbate peroxidase (APX), and catalase (CAT) activities in maize and soybean plants before applying the treatments.

\begin{tabular}{|c|c|c|c|c|}
\hline Crop & SOD & APX & CAT & Protein \\
\hline & \multicolumn{3}{|c|}{----- unit $\mathrm{mg}^{-1}$ protein } & $\mu g \mathrm{~mL}^{-1}$ \\
\hline Maize & 1.72 & 7.44 & 206.8 & 171.2 \\
\hline Soybean & 1.79 & 38.09 & 341.68 & 249.4 \\
\hline
\end{tabular}

Table 5 - Superoxide dismutase (SOD), ascorbate peroxidase (APX), and catalase (CAT) responses of maize and soybean plants to biostimulant 1 (BIO1) under two soil moisture levels.

\begin{tabular}{|c|c|c|c|c|c|c|c|}
\hline \multirow{3}{*}{ Treatment } & \multirow{3}{*}{ Dose } & \multicolumn{3}{|c|}{ Maize } & \multicolumn{3}{|c|}{ Soybean } \\
\hline & & \multicolumn{3}{|c|}{ Water content } & \multicolumn{3}{|c|}{ Water content } \\
\hline & & Drought & Well-watered & Mean $^{\dagger}$ & Drought & Watered & Mean $^{\dagger}$ \\
\hline & & \multicolumn{6}{|c|}{ SOD 42 days } \\
\hline & $\mathrm{L} \mathrm{ha}^{-1}$ & \multicolumn{6}{|c|}{ 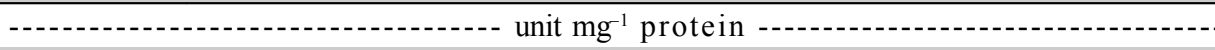 } \\
\hline Control & 0 & 1.30 & 1.82 & $1.56 \mathrm{a}$ & 1.08 & 1.02 & $1.05 \mathrm{a}$ \\
\hline 1 & 150 & 1.44 & 0.97 & $1.21 \mathrm{a}$ & 0.76 & 1.25 & $1.01 \mathrm{a}$ \\
\hline 2 & 300 & 1.49 & 1.82 & $1.66 \mathrm{a}$ & 0.62 & 0.79 & $0.70 \mathrm{a}$ \\
\hline \multirow[t]{3}{*}{ Mean ${ }^{\dagger}$} & & $1.41 \mathrm{x}^{\dagger}$ & $1.54 \mathrm{x}$ & & $0.82 \mathrm{x}^{\dagger}$ & $1.02 \mathrm{x}$ & \\
\hline & & \multicolumn{6}{|c|}{ SOD 60 days } \\
\hline & & $-\cdots-\cdots$ & - & --.-. unit $\mathrm{m}$ & tein -..--- & - - - - & - \\
\hline Control & 0 & 0.86 & 0.82 & $0.84 \mathrm{~b}$ & 1.11 & 0.66 & $0.88 \mathrm{a}$ \\
\hline 1 & 150 & 1.01 & 0.73 & $0.87 \mathrm{~b}$ & 3.19 & 1.04 & $1.89 \mathrm{a}$ \\
\hline 2 & 300 & 2.29 & 1.24 & $1.77 \mathrm{a}$ & 0.80 & 0.60 & $0.92 \mathrm{a}$ \\
\hline \multirow[t]{3}{*}{ Mean } & & $1.39 \mathrm{x}$ & $0.93 \mathrm{x}$ & & $1.70 \mathrm{x}$ & $0.76 \mathrm{x}$ & \\
\hline & & \multicolumn{6}{|c|}{ APX 42 days } \\
\hline & & $-\cdots---\cdot$ & $\cdots$ & -..- unit $m$ & tein -.-.- & & $\cdots-\cdots$ \\
\hline Control & 0 & 25.3 & 16.2 & $20.8 \mathrm{a}$ & 28.51 & 15.64 & $22.07 \mathrm{a}$ \\
\hline 1 & 150 & 39.8 & 23.0 & $31.6 \mathrm{a}$ & 36.15 & 25.29 & $30.72 \mathrm{a}$ \\
\hline 2 & 300 & 85.4 & 24.9 & $55.2 \mathrm{a}$ & 45.17 & 39.09 & $42.13 \mathrm{a}$ \\
\hline \multirow[t]{3}{*}{ Mean } & & $50.2 \times$ & $21.5 \mathrm{x}$ & & $36.61 \mathrm{x}$ & $26.67 \mathrm{x}$ & \\
\hline & & \multicolumn{6}{|c|}{ APX 60 days } \\
\hline & & - & - & --.-- unit $\mathrm{m}$ & tein -..-- & $-\cdots-\cdots$ & $\cdots-\cdots$ \\
\hline Control & 0 & 10.2 & 18.1 & $14.2 \mathrm{~b}$ & 35.2 & 31.65 & $33.43 \mathrm{a}$ \\
\hline 1 & 150 & 42.6 & 26.6 & $34.6 \mathrm{a}$ & 61.2 & 43.61 & $52.40 \mathrm{a}$ \\
\hline 2 & 300 & 39.4 & 31.6 & $35.5 \mathrm{a}$ & 41.1 & 37.53 & $39.33 \mathrm{a}$ \\
\hline \multirow[t]{3}{*}{ Mean } & & $30.7 \mathrm{x}$ & $25.5 \mathrm{x}$ & & $45.8 \mathrm{x}$ & $37.60 \mathrm{x}$ & \\
\hline & & \multicolumn{6}{|c|}{ CAT 42 days } \\
\hline & & $-\cdots \cdots \cdots$ & - & -..-.- unit $\mathrm{m}$ & tein -....- & $-\cdots-\cdots$ & 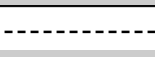 \\
\hline Control & 0 & 2095 & 774.2 & $1434 \mathrm{a}$ & 842.7 & 224.3 & $533.5 \mathrm{a}$ \\
\hline 1 & 150 & 1695 & 1546.3 & $1621 \mathrm{a}$ & 551.1 & 364.9 & $458.0 \mathrm{a}$ \\
\hline 2 & 300 & 1047 & 639.7 & 843 a & 252.0 & 336.8 & $294.4 \mathrm{a}$ \\
\hline \multirow[t]{3}{*}{ Mean } & & $1612.2 \mathrm{x}$ & $986.7 \mathrm{x}$ & & $548.6 \mathrm{x}$ & $308.7 \mathrm{x}$ & \\
\hline & & \multicolumn{6}{|c|}{ CAT 60 days } \\
\hline & & - & - & -.-.- unit $\mathrm{m}$ & tein --.-- & 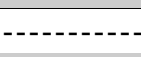 & - - - - \\
\hline Control & & 854.6 & 278.4 & $566.5 \mathrm{a}$ & 1262.3 & 407.5 & 834.9 a \\
\hline 1 & 0 & 530.5 & 521.1 & $415.4 \mathrm{a}$ & 926.2 & 392.2 & $659.2 \mathrm{a}$ \\
\hline 2 & 150 & 309.7 & 2906.5 & $1718.5 \mathrm{a}$ & 347.6 & 537.5 & $442.6 \mathrm{a}$ \\
\hline Mean & 300 & $564.9 \mathrm{x}$ & $1235.3 \mathrm{x}$ & & $845.9 x$ & $445.7 \mathrm{x}$ & \\
\hline
\end{tabular}

'Means within each column (a, b) or row (x, y) followed by the same letter are not different $(p<0.05)$. 
1 (Table 5). The doses of BIO2 enhanced SOD activities in maize and in soybean plants under both soil moisture levels at 42 days after seeding (Table 6). The APX activity in maize plants under both soil moisture levels was also enhanced by application of $\mathrm{BIO} 2$ at 60 days after seeding; and in soybean plants under drought stress at the same date (Table 6). No increase in these enzymes was measured due to application of BIO3 (Table 7). Catalase activity was en- hanced in soybean plants under watered soil moisture by application of BIO 1 (Table 5) and under drought level by application of BIO 2 (Table 6). The application of BIO 3 induced CAT activity increases in maize and soybean plants under drought soil moisture level (Table 7).

The biostimulants caused a slight improvement in antioxidant activities in maize and soybean plants. Probably, the low amounts of auxin were not able to

Table 6 - Superoxide dismutase (SOD), ascorbate peroxidase (APX), and catalase (CAT) responses of maize and soybean plants to biostimulant 2 (BIO2) under two soil moisture levels.

\begin{tabular}{|c|c|c|c|c|c|c|c|}
\hline \multirow{3}{*}{ Treatment } & \multirow{3}{*}{ Dose } & \multicolumn{3}{|c|}{ Maize } & \multicolumn{3}{|c|}{ Soybean } \\
\hline & & \multicolumn{3}{|c|}{ Water content } & \multicolumn{3}{|c|}{ Water content } \\
\hline & & Drought & Well-watered & Mean $^{\dagger}$ & Drought & Watered & Mean $^{\dagger}$ \\
\hline & & \multicolumn{6}{|c|}{ SOD 42 days } \\
\hline & $\mathrm{L} \mathrm{ha}^{-1}$ & \multicolumn{6}{|c|}{ - unit $\mathrm{mg}^{-1}$ protein -1} \\
\hline Control & 0 & 0.95 & 0.86 & $0.90 \mathrm{a}$ & 4.20 & 3.19 & $3.69 \mathrm{a}$ \\
\hline 1 & 0.5 & 1.02 & 0.89 & $0.95 \mathrm{a}$ & 3.41 & 2.92 & $3.16 \mathrm{a}$ \\
\hline 2 & 1 & 0.98 & 1.32 & $1.15 \mathrm{a}$ & 5.45 & 3.70 & $4.57 \mathrm{a}$ \\
\hline \multirow[t]{3}{*}{ Mean $^{\dagger}$} & & $0.98 \mathrm{x}^{\dagger}$ & $1.02 \mathrm{x}$ & & $4.35 \mathrm{x}^{\dagger}$ & $3.27 \mathrm{x}$ & \\
\hline & & \multicolumn{6}{|c|}{ SOD 60 days } \\
\hline & & \multicolumn{6}{|c|}{ - } \\
\hline Control & 0 & 0.82 & 0.61 & $0.71 \mathrm{a}$ & 3.46 & 1.28 & $2.37 \mathrm{a}$ \\
\hline 1 & 0.5 & 0.54 & 1.03 & $0.79 \mathrm{a}$ & 2.20 & 2.89 & $2.55 \mathrm{a}$ \\
\hline 2 & 1 & 0.78 & 0.63 & $0.70 \mathrm{a}$ & 1.95 & 1.14 & $1.54 \mathrm{a}$ \\
\hline \multirow[t]{3}{*}{ Mean } & & $0.71 \mathrm{x}$ & $0.76 \mathrm{x}$ & & $2.53 \mathrm{x}$ & $1.77 \mathrm{x}$ & \\
\hline & & \multicolumn{6}{|c|}{ APX 42 days } \\
\hline & & \multicolumn{6}{|c|}{ - } \\
\hline Control & 0 & 23.1 & 32.1 & 27.6 a & 21.6 & 23.2 & $22.4 \mathrm{a}$ \\
\hline 1 & 0.5 & 40.7 & 26.6 & $33.7 \mathrm{a}$ & 38.9 & 42.7 & $40.8 \mathrm{a}$ \\
\hline 2 & 1 & 37.5 & 11.8 & $24.6 \mathrm{a}$ & 39.1 & 24.9 & $32.0 \mathrm{a}$ \\
\hline \multirow[t]{3}{*}{ Mean } & & $33.8 \mathrm{x}$ & $23.5 \mathrm{x}$ & & $34.9 \mathrm{x}$ & $27.2 \mathrm{x}$ & \\
\hline & & \multicolumn{6}{|c|}{ APX 60 days } \\
\hline & & \multicolumn{6}{|c|}{ - unit $\mathrm{mg}^{-1}$ protein } \\
\hline Control & 0 & 24.9 & 17.1 & $21.0 \mathrm{a}$ & 33.5 & 28.3 & 30.9 a \\
\hline 1 & 0.5 & 24.4 & 15.3 & $19.8 \mathrm{a}$ & 26.5 & 32.4 & $29.5 \mathrm{a}$ \\
\hline 2 & 1 & 29.2 & 17.2 & $23.2 \mathrm{a}$ & 44.8 & 20.8 & $32.8 \mathrm{a}$ \\
\hline \multirow[t]{3}{*}{ Mean } & & $26.2 \mathrm{x}$ & $16.5 \mathrm{x}$ & & $33.2 \mathrm{x}$ & $30.2 \mathrm{x}$ & \\
\hline & & \multicolumn{6}{|c|}{ CAT 42 days } \\
\hline & & \multicolumn{6}{|c|}{ - } \\
\hline Control & 0 & 309.1 & 872.0 & 590.4 a & 117.6 & 339.6 & 228.6 a \\
\hline 1 & 0.5 & 480.2 & 258.0 & $369.3 \mathrm{a}$ & 318.8 & 1326.9 & 822.8 a \\
\hline 2 & 1 & 229.9 & 1026.0 & $627.9 \mathrm{a}$ & 474.2 & 344.1 & $409.2 \mathrm{a}$ \\
\hline \multirow[t]{3}{*}{ Mean } & & $339.7 \mathrm{x}$ & $718.6 x$ & & $303.5 \mathrm{x}$ & $670.2 \times$ & \\
\hline & & \multicolumn{6}{|c|}{ CAT 60 days } \\
\hline & & \multicolumn{6}{|c|}{ unit $\mathrm{mg}^{-1}$ protein } \\
\hline Control & 0 & 1256.4 & 870.8 & 1063.6 a & 307.3 & 526.3 & $416.8 \mathrm{a}$ \\
\hline 1 & 0.5 & 113.0 & 272.9 & $201.5 \mathrm{a}$ & 345.7 & 440.7 & $393.2 \mathrm{a}$ \\
\hline 2 & 1 & 853.4 & 493.6 & $673.5 \mathrm{a}$ & 472.9 & 493.9 & $483.4 \mathrm{a}$ \\
\hline Mean & & $746.6 \times$ & $545.7 \mathrm{x}$ & & $375.3 \times$ & $487.0 \mathrm{x}$ & \\
\hline
\end{tabular}

Means within each column $(\mathrm{a}, \mathrm{b})$ or row $(\mathrm{x}, \mathrm{y})$ followed by the same letter are not different $(p<0.05)$. 
enhance stress tolerance in plants subjected to water deficit in a definitive way. Some plant species are able to tolerate low water content in plant tissues, exhibiting growth and maintenance of metabolic processes even under cellular water deficit (McCann \& Huang, 2008).

The responses of plants to drought stress are highly complex, involving deleterious and/or adaptive changes. Early responses of plants to drought stress usually help the plant to survive for some time, while the acclimation of the plant subjected to drought is indicated by the accumulation of certain new metabolites associated with the structural capabilities to improve plant functioning under drought stress (Reddy et al., 2004). We speculate that the effects of the biostimulants did not materialize since plants were not subjected to soil moisture deficits of a severe enough nature.

Table 7 - Superoxide dismutase (SOD), ascorbate peroxidase (APX), and catalase (CAT) responses of maize and soybean plants to biostimulant 3 (BIO3) under two soil moisture levels.

\begin{tabular}{|c|c|c|c|c|c|c|c|}
\hline \multirow{3}{*}{ Treatment } & \multirow{3}{*}{ Dose } & \multicolumn{3}{|c|}{ Maize } & \multicolumn{3}{|c|}{ Soybean } \\
\hline & & \multicolumn{3}{|c|}{ Water content } & \multicolumn{3}{|c|}{ Water content } \\
\hline & & Drought & Well-watered & Mean $^{\dagger}$ & Drought & Watered & Mean $^{\dagger}$ \\
\hline & & \multicolumn{6}{|c|}{ SOD 42 days } \\
\hline & $\mathrm{L} \mathrm{ha}^{-1}$ & ---.-- & 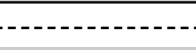 & -.-.- unit $\mathrm{m}$ & tein.-- & 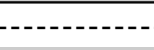 & ---------- \\
\hline Control & 0 & 1.09 & 1.31 & $1.20 \mathrm{a}$ & 0.99 & 0.73 & $0.86 \mathrm{a}$ \\
\hline 1 & 25 & 0.90 & 0.94 & $0.92 \mathrm{a}$ & 0.63 & 0.59 & $0.61 \mathrm{a}$ \\
\hline 2 & 50 & 1.10 & 0.90 & $1.00 \mathrm{a}$ & 0.74 & 0.55 & $0.64 \mathrm{a}$ \\
\hline \multirow{3}{*}{ Mean } & & $1.03 \mathrm{x}^{\dagger}$ & $1.05 \mathrm{x}$ & & $0.78 \mathrm{x}^{\dagger}$ & $0.62 \times$ & \\
\hline & & \multicolumn{6}{|c|}{ SOD 60 days } \\
\hline & & $---\cdot-\cdots-$ & $\cdots$ & -.-.- unit $\mathrm{m}$ & tein -.--- & -------- & 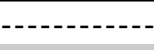 \\
\hline Control & 0 & 0.59 & 1.08 & $0.84 \mathrm{a}$ & 0.67 & 0.57 & $0.62 \mathrm{a}$ \\
\hline 1 & 25 & 0.82 & 0.50 & $0.66 \mathrm{a}$ & 0.42 & 1.10 & $0.77 \mathrm{a}$ \\
\hline 2 & 50 & 0.68 & 0.52 & $0.60 \mathrm{a}$ & 0.64 & 1.07 & $0.86 \mathrm{a}$ \\
\hline \multirow[t]{3}{*}{ Mean } & & $0.70 \mathrm{x}$ & $0.70 \mathrm{x}$ & & $0.58 \mathrm{x}$ & $0.91 \mathrm{x}$ & \\
\hline & & \multicolumn{6}{|c|}{ APX 42 days } \\
\hline & & 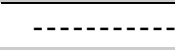 & ------- & unit $m$ & tein -...-. & ---------- & 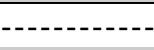 \\
\hline Control & 0 & 40.2 & 25.4 & $32.8 \mathrm{a}$ & 63.4 & 77.7 & 70.6 a \\
\hline 1 & 25 & 20.6 & 18.5 & $19.5 \mathrm{~b}$ & 68.9 & 82.8 & 75.9 a \\
\hline 2 & 50 & 20.2 & 13.4 & $16.8 \mathrm{~b}$ & 61.5 & 77.7 & $69.6 \mathrm{a}$ \\
\hline \multirow[t]{3}{*}{ Mean } & & $27.0 \mathrm{x}$ & $19.1 \mathrm{x}$ & & $64.6 \mathrm{y}$ & $79.4 \mathrm{x}$ & \\
\hline & & \multicolumn{6}{|c|}{ APX 60 days } \\
\hline & & --------- n & - & -..- unit $\mathrm{m}$ & tein -...-. & $-\cdots$ & $-\cdots$ \\
\hline Control & 0 & 22.9 & 23.4 & $23.2 \mathrm{a}$ & 30.9 & 35.8 & $33.3 \mathrm{a}$ \\
\hline 1 & 25 & 38.0 & 11.1 & $24.6 \mathrm{a}$ & 21.7 & 76.4 & $49.1 \mathrm{a}$ \\
\hline 2 & 50 & 28.2 & 13.4 & $20.8 \mathrm{a}$ & 23.3 & 24.8 & $24.1 \mathrm{a}$ \\
\hline \multirow[t]{3}{*}{ Mean } & & $29.7 \mathrm{x}$ & $16.0 \mathrm{x}$ & & $25.3 \mathrm{x}$ & $45.7 \mathrm{x}$ & \\
\hline & & \multicolumn{6}{|c|}{ CAT 42 days } \\
\hline & & $-\cdots-\cdots-$ & - & --.-- unit $\mathrm{m}$ & tein --.-- & $\cdots-\cdots$ & 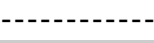 \\
\hline Control & 0 & 615.1 & 1202.8 & $909.0 \mathrm{a}$ & 632.9 & 336.3 & $484.6 \mathrm{a}$ \\
\hline 1 & 25 & 387.0 & 587.0 & $487.0 \mathrm{a}$ & 378.1 & 440.2 & $409.2 \mathrm{a}$ \\
\hline 2 & 50 & 1383.1 & 305.7 & $844.4 \mathrm{a}$ & 553.9 & 405.8 & $479.9 \mathrm{a}$ \\
\hline \multirow[t]{3}{*}{ Mean } & & $795.1 \times$ & $698.5 \mathrm{x}$ & & $521.6 \mathrm{x}$ & $394.1 \times$ & \\
\hline & & \multicolumn{6}{|c|}{ CAT 60 days } \\
\hline & & - - - - - & (n-1-n & ---- unit $\mathrm{m}$ & tein ---.. & ------ & - n-n \\
\hline Control & 0 & 899.0 & 836.3 & 867.9 a & 269.1 & 500.8 & 384.9 a \\
\hline 1 & 25 & 961.0 & 199.4 & $580.1 \mathrm{a}$ & 436.9 & 1011.0 & $723.9 \mathrm{a}$ \\
\hline 2 & 50 & 1288.0 & 968.5 & $1128.4 \mathrm{a}$ & 469.9 & 719.5 & $594.7 \mathrm{a}$ \\
\hline Mean & & $1049.5 \mathrm{x}$ & $668.1 \mathrm{x}$ & & $392.0 \mathrm{x}$ & $743.8 \mathrm{x}$ & \\
\hline
\end{tabular}

'Means within each column (a, b) or row (x, y) followed by the same letter are not different $(p<0.05)$. 
Superoxide dismutase is the first line of defense against ROS caused by environmental stresses such as drought with transient increases in SOD activity consistently being associated with increased stress tolerance (Zhang et al., 2005; Gratão et al., 2005; Foyer \& Noctor, 2000). However, various authors have reported unchanged activity (Luna et al., 1985; Moran et al., 1994), increase (Luna et al., 1985; Tezara \& Lawlor, 1995; Wang \& Huang, 2004), and decrease (Quartacci \& Navari-Izzo, 1992; Wang \& Huang, 2004) in SOD activity.

Ascorbate peroxidase activity (APX) breaks down hydrogen peroxide efficiently using ascorbate as substrate. However, some researchers have related decreases in this enzyme at drought stage. Zhang \& Kirkham (1996) found decreasing in APX activity in sorghum plants cultivated under drought stress and stated that ascorbate participates in the removal of hydrogen peroxide without APX activity.

Catalase activity responds to drought in many ways: it can increase, decrease or remain unchanged (Smirnoff, 1993; Zhang \& Kirkham, 1996; Zgallaï et al., 2006). Relative to the alternative $\mathrm{H}_{2} \mathrm{O}_{2}$ scavenging systems, catalases are distinguished by very high turnover numbers but rather low affinities toward $\mathrm{H}_{2} \mathrm{O}_{2}$ (Nicholls et al., 2001). Consequently, catalases provide very efficient tools for the gross removal and control of high $\mathrm{H}_{2} \mathrm{O}_{2}$ levels, but they are less suited for a fine tuning of sensitive redox balances with low $\mathrm{H}_{2} \mathrm{O}_{2}$ concentrations that may be important for regulatory mechanisms. Catalase do not depend on any additional reductant for the scavenging of $\mathrm{H}_{2} \mathrm{O}_{2}$, representing a major advantage of this enzyme (Feierabend, 2005).

Investigations on the role of biostimulants in the physiological mode of action in plants subjected to drought stress are currently underway. Considerable researches remain to be completed to gain a clearer understanding of these products increase the physiological health of plants under environmental stress. The composition of biostimulants should present a variety of organic materials such as humic substances, seaweed extracts, organic matter, and amino acids in order to improve stress tolerance.

\section{ACKNOWLEDGEMENTS}

This research was funded by CAPES (Coordenação de Aperfeiçoamento de Pessoal de Nível Superior). The authors are very grateful to the Daymsa, LBE Biotecnologia, and Provaso companies for supporting this research.

\section{REFERENCES}

AKANDE, M.O. Effect of organic root plus (biostimulant) on the growth, nutrient content and yield of amaranthus. African Journal of Biotechnology, v.5, p.871-874, 2006.

ARTLIP, T.S.; WISNIEWSKI, M.E. Induction of proteins in response to biotic and abiotic stresses. In: PESSARAKLI, M. (Ed.) Handbook of plant and crop physiology. New York: Marcel Dekker, 2002. p.657-679.

CANELLAS, L.P.; TEIXEIRA JUNIOR, L.R.L.; DOBBSS, L.B;. SILVA, C.A.; MEDICI, L.O. ZANDONADI, D.B.; FAÇANHA, A.R. Humic acids crossinteractions with root and organic acids. Annals of Applied Biology, v.153, p.157-66, 2008.

CASTRILLO, M.; FERNANDEZ, D.; TRUJILLO, I; GUENNI, L. Responses of ribulose-1,5-biphosphate carboxylase, protein content, and stomatal condcutance to water deficit in maize, tomato, and bean. Photosynthetica, v.39, p.221-226, 2001.

CHANCE, B.; MAEHLY, A.C. Assay of catalase and peroxidases. Methods Enzymology, v.2, p.764-775, 1995.

DELFINE, S.; TOGNETTI, R.; DESIDERIO, E.; ALVINO, A Effects of foliar application of $\mathrm{N}$ and humic acids on growth and yield of durum wheat. Agronomy for Sustainable Development, v.25, p.183-191, 2005 .

EYHERAGUIBEL, B.; SILVESTRE, J.; MORARD, P. Effects of humic substances derived from organic waste enhancement on the growth and mineral nutrition of maize. Bioresource Technology, v.99, p.4206-4212, 2008.

FEIERABEND, J. Catalases in plants: molecular and functional properties and role in stress defense. In: SMIRNOFF, N. (Ed.) Antioxidants and reactive oxygen species in plants. Oxford: Blackwell, 2005. p.101-140.

FOYER, C.H.; NOCTOR, G. Oxygen processing in photosynthesis: regulation and signalling. New Phytologist, v.146, p.359-388, 2000

GIANNOPOLITIS, C.N.; RIES, S.K. Superoxide dismutase. I Occurrence in higher plants. Plant Physiology, v.59, p.309$314,1977$.

GRATÃO, P.L.; POLLE, A.; LEA, P.J.; AZEVEDO, R.A. Making the life of heavy metal-stressed plants a little easier. Functional Plant Biology, v.32, p.481-494, 2005.

KAUFFMAN III, G.L.; KNEIVEL, D.P.; WATSCHKE, T.L. Effects of a biostimulant on the heat tolerance associated with photosynthetic capacity, membrane thermostability, and polyphenol production of perennial ryegrass. Crop Science, v.47, p.261-267, 2007.

LUNA, M.; BADIANI, M.; FELICI, M.; SERMANNI, G.G. Selective enzyme inactivation over water stress in maize (Zea mays L.) and wheat (Triticum aestivum L.) seedlings. Environmental and Experimental Botany, v.25, p.153-156, 1985.

MALAN, C.; GREYLING, M.M.; GRESSEL, J. Correlation between $\mathrm{Cu} / \mathrm{Zn}$ superoxide dismutase and glutathione reductase, and environmental and xenobiotic stress tolerance in maize inbreeds. Plant Science, v.69, p.157-166, 1990.

McCANN, S.E.; HUANG, B. Evaluation of drought tolerance and avoidance traits for six creeping bentgrass cultivars. HortScience, v.43, p.519-524, 2008.

MORAN, J.F.; BECANA, M.I.; FRENCHILLA, S.; KLUCAS, R.V.; APARICIO-TEJO, P. Drought induces oxidative stress in pea plants. Planta, v.194, p.346-352, 1994.

MULLINS, G; HECKENDORN, S. Soil test notes 1-4. Blacksburg: Virginia Tech, 2005. 155p. (Virginia Cooperative Extension. Agricultural and Extension Communications, .834).

NAKANO, Y.; ASADA, K. Hydrogen peroxide is scavenged by ascorbate-specific peroxidase in spinach chloroplasts. Plant Cell Physiology, v.22, p.867-880, 1981.

NICHOLLS, P.; FITA, I.; LOEWEN, P. Enzymology and structure of catalases. Advances in Inorganic Chemistry, v.51, p.51$106,2001$. 
NOCTOR, G.; FOYER, C.H. Ascorbate and glutathione: keeping active oxygen under control. Annual Review of Plant Physiology and Plant Molecular Biology, v.49, p.249-279, 1998.

O'DONNELL, R.W. The auxin-like effects of humic preparations from leonardite. Soil Science, v.116, p.106-112, 1973.

PERL, A.; PERL-TREVES, R.; SHALGI, E.; MALKIN, S.; GALUN, E. Enhanced oxidative stress defense in transgenic tobacco expressing tomato $\mathrm{Cu}, \mathrm{Zn}$ superoxide dismutase. Theoretical and Applied Genetics, v.85, p.568-576, 1993.

QUARTACCI, M.F.; NAVARI-IZZO, F. Water stress and free radical mediated changes in sunflower seedlings. Journal of Plant Physiology, v.139, p.621-625, 1992.

RAHMAN, S.M.L.; MacKAY, T.; QUEBEDEAUX, B. Superoxide dismutase and stress tolerance of four tomato cultivars. Hortscience, v. 39, p.983-986, 2004.

REDDY, A.R.; CHAITANYA, K.V.; VIVEKANANDAN, M. Drought-induced responses of photosynthesis and antioxidant metabolism in higher plants. Journal of Plant Physiology, v. 161, p. $1189-1202,2004$

SAS INSTITUTE. SAS/STAT user's guide. Cary: SAS Institute, 2002.

SMITH, P.K. Measurement of protein using bicinchoninic acid. Analytical Biochemistry, v.150, p.76-85, 1985.

TEZARA, W.; LAWLOR, D.W. Effects of water stress on the biochemistry and physiology of photosynthesis in sunflower. In: MATHIS, P. (Ed) Photosynthesis: from light to biosphere. Dordrecht: Kluwer, 1995. p.625-628.

WANG, Z.; HUANG, B. Physiological recovery of Kentucky bluegrass from simultaneous drought and heat stress. Crop Science, v.44, p.1729-1736, 2004
YOPP, J.H.; AUNG, L.H.; STEFFENS, G.L. Bioassays and other special techniques for plants hormones and plant growth regulators. Lake Alfred: Plant Growth Regulator Society of America, 1986. 208p.

ZGALLAÏ, H.; STEPPE, K.; LEMEUR, R. Effects of levels of water stress on leaf water potential, protein and chlorophyll content and anti-oxidative enzymes in tomato plants. Journal of Integrative Plant Biology, v.48, p.679-685, 2006.

ZHANG, J.; KIRKHAM, M.B. Antioxidant responses to drought in sunflower and sorghum seedlings. New Phytologist, v.132, p.361-373, 1996.

ZHANG, X.; ERVIN, E.; EVANYLO, G; SHERONY, C.; PEOT, C. Biosolids impact on tall fescue drought resistance. Journal of Residuals Science \& Technology, v.2, p.173-180, 2005.

ZHANG, X.; ERVIN, E.H. Cytokinin-containing seaweed and humic acid extracts associated with creeping bentgrass leaf cytokinins and drought resistance. Crop Science, v.44, p.1737-1745, 2004.

ZHANG, X.; ERVIN, E.H.; SCHMIDT, R.E. Plant growth regulators can enhance the recovery of Kentucky bluegrass sod from heat injury. Crop Science, v.43, p.952-956, 2003.

ZHANG, X.; SCHMIDT, R.E. Hormone-containing products' impact on antioxidant status of tall fescue and creeping bentgrass subjected to drought. Crop Science, v.40, p.1344-1349, 2000.

Received June 03, 2008

Accepted November 14, 2008 